\title{
Investment Aspects of Regional Development
}

\author{
Prof. Ass. Dr. Nerimane Bajraktari \\ Economic Faculty, University of Prizren "Ukshin Hoti"
}

\section{Doi:10.5901/ajis.2015.v4n2p551}

\begin{abstract}
By the abstract fact that history has presented various theories of economic development, and different determinant of this development are emphasized (the human race, culture, customs, mentality, experiences, etc.), it is more acceptable, however, that when we talk about development problems, there are various determinants of economic development to be considered. Questions related to optimal relation between the development by sectors and the regional one, as well as to coordination between the sector policy and regional one in national level, remain actual and central.
\end{abstract}

Keywords: regional development, expansion, contraction, conversion, integration

\section{The Problem of Regional Development}

The core problem of regional development is very complex, especially the methodological procedure and the relevant technical instrument for the extraction and measurement of relevant assessments of the quality and quantity of their development. All this gets more complicated when we have to deal with the development of their economic subjects (enterprises) having in mind the different kinds of regions.

It would be wrong to think that the existence, functioning and development of regions and their sub-regions can be done solely by themselves. On the contrary, various factors, be them internal and external, objective and subjective, in various time periods, in different ways impact the ways of behaviour of that development.

It should immediately accepted that "a simple increase in the number of residents cannot show the development". This has been observed long time ago from R.Malfus, stressing that the uncontrolled growth of the number of residents, surely, can condition the action of the law of lower revenues, and with this, the reduction of per capita vital standard, which is contrary to the fundamental purpose of economic development. The population of a country, as a potential source of human labour (as a subjective category) is "conditio sine quo non" of every successful economic development. For this, it is a more relevant criterion of tempo and intensity of economic development, not only in quantitative terms.

Thus, since the population is a more complex economic categories (total number of residents, the contingent of residents capable of working, the ratio between the sexes of residents, qualification structure, "hidden unemployment" quantum, the volume of real unemployment, mortality and birth percentage, territorial placement of different categories, the influx of residents capable of working, their immigration and emigration, etc.), a permanent escort is necessary, and an analytical following of all its aspects, in order for the design of this important determinant of economic development to be as objective and precise, in order to successfully carry it. Neglecting this subjective determinant would result in inevitable consequences of inconsistency in the functional process of development, and with this, dispersion and no commitment.

Science and practice have noticed long ago that a linear development of regions, sub-regions, and their enterprises is impossible. On the contrary, the general belief has been approved that "these spatial-economic categories present the so-called adaptive-rational systems, in a necessary and elastic way they have to adjust to the regulations of behavior" (A.O. Hirscgman, "The strategy of economic development", Yabe University, New York 1998, pg. 58) in different, dynamic conditions of the development.

Related to this, practice has investigated in a merit order, while science with specific methods has verified the knowledge that the next development paths of all economic subjects (including regions and sub-regions) have characteristics of development lawfulness, expansion, contraction, conversion and integration.

\section{Expansion}

Expansion represents a sensational growth of the region (its sub-region and its enterprises) which expresses in the 
growth of business volume, especially the fields with comparative advantages, as well as in the heightening of the total income and growth of the employment rate. Regional expansion is conditioned with an increased internal and external demand of specific productions, as well as strengthened demand for handicraft production activity and services of all kinds.

It is considered that all developed countries are, in most geographical areas with measured climates. Due to the fact that all tropical countries are mainly poor, it is a widespread opinion that this is just a consequence of this climate. However, such a stereotypical opinion, does not answer objective facts, with good reason noticed P. Samuelson, when he says: "Climate obviously is an important factor, but it is not that almighty" 2. The truth is, further, that the geographical distribution of natural blessings such as: the superior part of the soil, precipitation, water power for irrigation and hydropower production, rich ores, oil, etc.) represents a very important determinant of economic development in certain countries. However in the modern world which uses efficient commercial and transport communications, eliminating the possibility for serious shortcomings in the very objective of geographical distribution of natural bounties is higher every day (pronounced examples are Denmark, Japan, and Israel).

On the other hand, there are opinions of some economists on still undiscovered geographical regions that are brimming with natural wealth. However economic geographers, based on their new research have mainly denied these hopes and have found that people have occupied the most productive lands. At the same time it must be admitted that modern geologists, always discover hidden natural treasures, and frequent examples are of large complexes as training ground for agricultural exploitation through contemporary cutting and cleaning jungles and drying of the land ares with marshes. Also, economic geographers, they point out that the current economic development, largely depends on the best use of natural resources, and in perspective, more from innovative actions and adequate findings.

However, quantum and natural blessings structures of a country are important objective determinants of its economic growth and the choice of strategy and policy's development. Depending on the how many and which natural resourses a country has (working surface land, rivers, lakes, sea surface, forests, ores and the possibility of their exploitation, oil resources and the possibility of their exploitation, terrestrial and air ways, etc.) the choice of strategy and economic development policy will be easier to define and objectively define and are therefore better enforcement methods and instruments for its faster and successful implementation, However, by noticing that "the problems of the development of economic blessings comply with the problematic of improved technology and capital raising abilities to use existing natural blessings and the discovery of new ones.

\section{Contraction}

Contraction, as a negative direction of regional development, is presented in the reduction of the overall business volume of all activities, especially the primary one, which does not mean that as a consequence it has overall negative financial results, but, in every case the valued intensity of the entire regions' economy drops.

An important function of the economic development is capital collection which represents the contents of capital understanding. Capital is, before anything else, an important factor of any production, without which criteria does not exist for just any economic development. Capital, or capital goods, contains different things: various kinds of machines, economic buildings, installations, large interiors, tools, raw resources, ready-made productions and other means of production. According to some social criteria, market values of these physical goods can be gathered to win the overall capital. Capital represents value in financial means that contain the social report of exploitation of workers from the capitalists that, at the same time, bring over the capital owners' value in the capital production reports.

\section{Conversion}

Conversion as the third way of the next economic regional development, underlies a big change of the business program in the main part of the economic activity. It is understood that the causes of this occurrence are the internal changing conditions of the main enterprises, but in a big scale, it is the market situation within the region, as well as disordered inter-regional relations. The difficulty of the conversion phase consists of the fact that the changes of the business programs of the main activities most often cannot be applied by using existing business tools, but they have to be reconstructed and modernized. This problem because of its complexity requires that firstly it should be forecasted that it should gradually win the character of "common preparatory action" of all the factors interested within that region. (Myrdal G. "Ekonomska teorija I nerazvijeni regioni", London 1997 pg. 189) 


\section{Integration}

Lastly, integration as the next direction of regional economy must be presented in a permanent business cooperation (coordination) with one or more regions that have a similar structure, or are functionally complementary with the common aim of achieving better socio-economic results with importance to the overall development of the entire region. However, this next economic direction of regions and their economic and social fields requires conscious and planned businesspolitical concepts and decisions and operational actions (definition of common optimal business programs, processing of relevant market topography, change of qualifying employee structures, permanent education, permanent innovations of professional occurrences, etc.).

All this leads to the conclusion that the development of regions, its sub-regions, and primary enterprises in some economic activity with a booster character, is not linear but is affected by timely changes and economic oscillations, which cannot always be forecasted and be regulated with "decisive regulations:, much less from their true causes, can be dedicated to inadequate concepts, irrational regionally planned, and operative actions. Because of this, the development and growth of the region and the primary economic fields is conditioned with an objective pass through the above mentioned characteristic phases, that is why it requires leadership of a permanent policy which is developmentconscious, for which, scientists and professionals, with a full respect for a democratic free market process, will observe and study all the relevant changes and the factors ensuring its continuous development.

From what was said above, results that the creation of a development plan and the definition of the tools needed for its successful realization, brings us, unconditionally, to confront the investment needs on relevant tools which represent important factors of the development. In reality, here it comes to over-projection in a time of modernization and reconstruction of existing business capacities of primary, secondary, and tertiary economic activities, and the projection of new business capacities in accordance with the impact of internal factors and the dynamic of market determinants on one hand, and the progress technical-technological progress on the other hand.

When it comes to investment aspects of regional development, then it should be considered that it is a voluminous and complicated problem, which underlies respecting many methods, norms, criteria and determinants which limit a rational and efficient investment overall, especially when it comes to regions and their typological characteristics. In the recent decades, solely because of the complexity of the investment problems, especially for organizational and methodological reasons, a special scientific discipline originated and is continuously developing, called "organization of leadership with investments". (A.E. G. Robinson, "Teorija lokacije, regionalne rkonomije", New York 1996, fq. 84)

Along with this, within the region there should exist a coordinating staff, which must continuously follow and solve a number of investment tasks, investment policies, the scientific-technical correlation of progress and investment projects, work on investment programs, reasonableness evaluation of investment programs, preparation of investment realization, application of quantitative methods, implementation of the evaluation of investment projects from international banks for reconstruction and development, respectively the assessment of project break even.

Finally, in the investment problems of regional development a thought must be approved that there exists the problem of the hierarchy of regional and national development planning aims, which often are not compatible, and can bring deviation of the maximization of the overall income in the report at the maximization aims for regional income. Provided that they are harmonious and compatible, then they can condition the dynamic of the overall economic growth. However, even though investment in regions less productive and with less fruitful resources can bring overall weaker results. Looking at it from a long-term point of view, the effects can be much bigger.

\section{References}

A.O. Hirscgman, "The strategy of economic development", Yabe University, New York 1998, fq. 58

A.E. G. Robinson, "Teorija lokacije, regionalne rkonomije", New York 1996, fq. 84

Boris Zver, Teorija I praksa odluçivanja, 1980, g.

Dr Janko Gogiç, "Razvoj teorijske misli o regionalnom razvoju", Ekonomski fakultet, Podgorica 1998.

Myrdal G. "Ekonomska teorija I nerazvijeni regioni", London 1997 fq. 189

H. Richardson, "Regional Development, Chicago-London, 1998

Hirscgman A. O. "The strategy of Economic Development" Yale University Press, New York

Samuelson P. A. "Ekonomija, Savremena Administracija", Belgrade 1996

Shumpeter I. "Teorija e Zhvillimit Ekonomik" 1934 
